in part, by their difficulty in manœuvring for space. It was extremely difficult for all three fish to be completely at the surface at one time.

The fish were returned to the running-water pool after $1.5 \mathrm{hr}$. In the pool they continued to stay at the surface, moving about but not going to the bottom at all. $2 \mathrm{hr}$. later thoy were still at the surface. Normal carp cluster at the bottom even when food is introduced: the fish affected by LSD-25 ignored food scattered in the pool.

Preliminary experiments have shown that Eastern brook trout did not react to LSD-25 in a similar manner to carp.

Experiments with LAE-32 showed that $2 \mu \mathrm{gm}$. per ml. also induced surfacing behaviour of large carp, but this compound takes longer to act and the carp did not remain as consistently at the surface as with a similar concentration of LSD-25.

The mechanism of action of LSD-25 on carp is unknown. As we have shown previously ${ }^{6}$, certain oxidase poisons like sodium azide act in the same way as LSD-25 on Siamese fighting fish. The surfacing behaviour of Siamese fighting fish may also be readily brought about by simple anoxia. It would appear that LSD-25 probably acts by poisoning one of the many oxidase systems which are found in living tissue, as the action of LSD-25 occurs whether it is injected intraperitoneally or placed in the external liquid. As a matter of fact, the regression lines for the reaction-dose curves of LSD-25, whether in the external liquid or injected, and the curves for injected psiloeybin, are all parallel (Abramson, unpublished work).

Experiments in larger tanks, and field trials, are planned to investigate the surfacing behaviour and the edibility of fish exposed to compounds like LSD-25 and LAE-32.

This research was supported, in part, by a grant from Sandoz Pharmaceuticals, Hanover, N.J.

1 Loeb, H. A., and Kelly, W. H., New York Fish and Game Journal, $7,160(1960)$.

${ }^{2}$ Loeb, H. A., New York Fish and Game Journal, 2, 220 (1955); 4, 109 (1957) (personal communication).

${ }^{3}$ Abramson, II. A., Rolo, A., Sklarofsky, B., and Stache, J., $J$. Psychol., 49, 151 (1960).

4 Abramson, H. A., and Evans, I. T., Science, 120, 990 (1954).

5 Evans, L. T., Geronimus, L. H., Kornetsky, C., and Abramson, H. A., Science, 123, 26 (1956).

- Abramson, H. A., Weiss, B., and Baron, M. O., Nature, 181, 1136 (1958).

\title{
OBITUARIES
}

\section{Dr. H. H. Mann}

THe death on December 2 of Harold Hart Mann ended a life of research, remarkable alike for the varied subjects on which he left his mark and for the enthusiasm with which he carried on his work up to his death at the age of eighty-nine. He took his degree in chemistry from the Yorkshire College, later to become the University of Leeds, after which his interest in microbiology took him to the Pasteur Institute in Paris on the award of an 1851 Exhibition, where his work resulted in his first scientific paper, dealing with the effect of antiseptics on the growth of yeast. This also led to his first post, which he held for five years from 1895, that of assistant in chemistry and microbiology to Dr. J. A. Voelker, chemist to the Royal Agricultural Society and director of the Experimental Station at Woburn that was set up by the Society under the patronage of the Duke of Bedford.

This appointment gave Mann a lasting interest and affection for the Station, to which he was to return in later years. He went to India in 1900 as scientific adviser to the Indian Toa Association, later becoming principal of the Poona Agricultural College and agricultural chemist to the Bombay Government, posts which he held until appointed director of agriculture for Bombay Presidency in 1918. During his stay in India his researches on the cultivation of tea and on its diseases and pests revolutionized the culture of this crop, on which he became an accepted authority. Indeed, he acquired a reputation that became almost legendary, and resulted in three visits to the U.S.S.R. between 1930 and 1933 and other visits to countries in East Africa and the Middle East, where his authoritative advice was sought.

Mann returned to Britain in 1928 to take control of the farm and experiments at Woburn Experimental Station, which had recently come under the direction of Rothamsted Experimental Station. At Woburn, as in India, his researches covered a wide field. One of his main interests lay in problems of plant competition. This included competition between plants of the same species, between clover and rye grass and between barley and certain weed species. $\mathrm{H} \Theta$ also carried out experiments for many years on clover sickness and studied the function of organic manures, the effects of green manure crops and leys and the practical possibilities of such erop plants, unusual in Britain, as maize and soy beans. He found time for such investigations in addition to his duties in managing the farm and conducting long-term field experiments which have made the Woburn Station so valuable an adjunct to Rothamsted.

$\mathrm{He}$ continued his active research even after his retirement in 1956 at the age of eighty-four, and was preparing some of his results for publication when he met his death. To the end his inquiring mind remained a source of stimulus to his colleagues, and his infectious enthusiasm, kindliness and generosity will long be remembered by his very numerous friends.

GERARD THORNTON

Harold ManN was one of the last survivors of the band of pioneers who, in the early 1890 's, started to awaken agricultural chemistry from the torpor into which it had fallen in Britain, and setting it on the path which it has since followed with considerable success. His training under Dr. J. A. Voelcker had made him a very careful and conseientious analyst and field experimenter, and his readiness to adopt new ideas and new methods enabled him to make a new approach to old problems, so bringing them nearer to solution.

His studies of tea cultivation cleared the way for much more efficient management, but his work at the Poona Agricultural College and later as director of agriculture in the Bombay Presidency had far wider-reaching effects. It came at a time when great irrigation developments were requiring new and more highly productive systems of cropping and soil management, and with characteristic vigour he 